\title{
Public Spaces as a Venue for Peacebuilding in Lebanon. The Role of Civic Movements in Reclaiming Public Spaces in Beirut and Tripoli
}

\author{
Aseel Naamani, Ruth Simpson \\ International Alert, Lebanon \\ ANaamani@international-alert.org | RSimpson@international-alert.org
}

\begin{abstract}
The issue of public spaces is increasingly at the core of civic movements and discourse of reform in Lebanon, having come to the fore most recently in the mass protests of October 2019. Yet, these most recent movements build on years of activism and contestation, seeking to reclaim rights to access and engage with public spaces in the face of encroachments, mainly by the private sector. Urban spaces, including the country's two biggest cities - Beirut and Tripoli - have been largely privatised and have become the preserve of an elite few, and post-war development has been dogged by criticism of corruption and exclusivity. This article explores the history of public spaces in Beirut and Tripoli and the successive civic movements that have sought to realise rights to public spaces. It argues that reclaiming public spaces is central to reform and rebuilding relationships across divides after years of conflict as a cornerstone of peacebuilding efforts. First, the article describes the evolution of Lebanon's two main urban centres. Second, it discusses the role of the consociation system in the partition and regulation of public spaces. It goes on to describe the various civic movements related to public spaces and examines the opportunities created by the October 2019 movement. It then interrogates the limits imposed by COVID-19 and recent crises. Lastly, it explores how placemaking and public spaces can contribute to peacebuilding, and concludes that public spaces are essential to relationships and inclusive participation in public life.
\end{abstract}

Keywords: public spaces, civic movements, peacebuilding, urban development, Lebanon

To cite this article:

Naamani, A., Simpson, R. (202I) Public Spaces as a Venue for Peacebuilding in Lebanon. The Role of Civic Movements in Reclaiming Public Spaces in Beirut and Tripoli, The Journal of Public Space, 6(I), 25-46, DOI I0.3289I/jps.v6il.I324

This article has been double blind peer reviewed and accepted for publication in The Journal of Public Space. (c) (9) This work is licensed under a Creative Commons Attribution - Non Commercial 4.0 International License https://creativecommons.org/licenses/by-nc/4.0/ 


\section{Fragile foundations - an introduction to urban spaces in Lebanon}

The factors shaping urban fragility or safety are diverse; they include institutions, norms, economic opportunities and inequalities, infrastructure, and behavioural attitudes (Altpeter, 2016), which interact to shape the extent to which urban public spaces are safe, accessible and inclusive to all.

In Beirut and Tripoli, stability and safety rest, to a large extent, in the hands of influential networks that benefit from the weakness of the formal institutions to provide services and security. The result is urban spaces where dominion is divided between the state and informal networks. Often, the security situation in cities is seen as a direct outcome of the presence and the performance of state institutions, or the lack thereof (Altpeter, 2016). In that sense, fragility relates less to physical threats and more to indirect forms of violence that are reproduced along collective beliefs, values or norms, and impact how people relate to each other within societal and institutional structures leading to inequality, discrimination and injustice (Reyes, 2015). Examples of such fragility in both cities can be traced to the common practice of private security and valet parking firms limiting access to public spaces, such as sidewalks and parking spaces, with the tacit approval of the state (Kanafani, 2017), or to restaurants and bars taking over sidewalks and limiting people's spaces for walking freely.

Public spaces are defined as all places publicly owned or of public use, accessible and enjoyable by all for free and without a profit motive and they consist of open environments (e.g. streets, sidewalks, squares, gardens, parks) and sheltered spaces created for everyone's enjoyment (e.g. public libraries, museums) (Biennale Spazio Pubblico, 2013). They are thus instrumental in contributing to urban development and preserving cities' social fabric. Public spaces and social movements are interconnected and the nationwide movement of October 2019 is a manifestation of how people's relation to public spaces and democratic practices play out to shape urban development.

The streets and other shared spaces are increasingly acknowledged as hitherto underexplored vectors for peacebuilding where ideas and values are negotiated and contested (Bollens, 2006; Altpeter, 2016). The juxtaposition of movements reclaiming space in a context of increasing restrictions imposed by the COVID-19 pandemic has underlined the imperative to rethink the use of public spaces.

\section{The politics of public spaces}

Lebanon's consociation model of democracy places great emphasis on negotiation among political elites, whose role is seen as central in moderating inter-group conflicts as they represent the major religious sects in Lebanon. The elite is committed to preserving this power-sharing system through engaging in a series of exchanges of services provided by politicians in return for popular support. The result is continuous negotiations among the elite to maintain supremacy, and networks of supporters that thrive on political clientelism. These bargains extend to physical and political encroachments on state assets and public spaces.

The civil war military groups later became part of post-war governments after 1990, splitting executive power among themselves and making these encroachments either directly or through their clientelist networks. They legalised the encroachments and allowed random construction by such clientelist networks for profit. Beirut is thus 
losing its architectural heritage and cultural buildings, which are being replaced with towers and cement buildings, a trend that started after the end of the civil war.' Clientelism has limited technocratic ability to have a long-term and nationwide vision of urban planning. In 2018, Public Works, a Lebanese research and design studio that works on urban and public issues, conducted an urban planning review, which indicated that unplanned land accounted for $85 \%$ of the territory mapped. It identified "how factors such as law, property, identity, and interests contributed to displacing people's imagination, social fabric, livelihoods, and sometime entire neighbourhoods". (Public Works, 2018).

\section{Evolving public spaces in Beirut and Tripoli - urbanisation and privatisation} The 'rise' of Beirut as an urban centre with a war legacy

Modern-day Beirut is largely privatised (Monroe, 2016). The city's green spaces have also shrunk over the past decades, with only Horsh Beirut open to the public at specific times of the day. The other few open areas around Downtown Beirut are designed with modern structures and remain of very little use to the average citizen. The country's coastline has been vastly privatised by beach resorts. The only remaining public beach in Beirut, Ramlet al-Bayda, is under constant threat of encroachment by real estate developers, leaving people with limited access. A lack of regulation of wastewater management has also rendered it among the most polluted beaches in the country, which prevents residents from using it.

Many of Beirut's current public spaces and past battlefields overlap, and the interactions between its inhabitants in those spaces are defined by their memories and experiences of the political and sectarian violence of the civil war; such memories have never been resolved and are perpetuated by the country's ever-frail political climate.

The development of Beirut as an urban centre dates back to the Ottoman period (1860-19/4) when the city gained prominence as an economic hub, attracting foreign investments and increasing rural-to-urban migration (Monroe, 2016). Before that, successive civilisations, including the Canaanites, Phoenician, Hellenistic, Roman and Islamic, all left their mark on the city's landscape (Jehl, 1997). Throughout the nineteenth century, rural migrants transformed Beirut from a small town into a major seaport economic hub on the eastern Mediterranean (Fawaz, 1983). Many of these migrant families kept ties to their villages, facilitated by the development of roads. However, in a socialisation sense, they had become 'Beirutis', as in residents of an urban polity that is governed by a municipal council rather than by the charitable religious institutions, sectarian communities and feudalism that comprised village life (AbouHodeib, 20II).

During the French colonial period, Beirut became the centre of French culture, with many streets and squares renamed after their military men. The city's Downtown centre was a focal point for the mandate authorities, and so its design and use were imposed by the French colonial authorities (Monroe, 2016) creating boulevards and buildings imitating Paris's streets. Government and residential buildings, such as those in the Achrafieh neighbourhood in east Beirut, gave the city a distinctly French character.

\footnotetext{
' Interview with Mohammad Ayoub, Director of the Lebanese NGO NAHNOO that advocates for public spaces in Lebanon, conducted by Aseel Naamani on 7 July 2020 in Beirut, Lebanon.
} 
By changing the city's layout, the French authorities enacted a system of spatial control, with wide, straight boulevards radiating from the squares, which enabled surveillance, military movement and crowd control (Rabbat, 20I2).

Urbanisation and economic development in Beirut also brought a new sphere of public life, one that was characterised by cafes, theatres, clubs, public gardens, horse racing viewed from within a European-style hippodrome and roads designed for automobiles. Parks, such as Horsh Beirut, acquired features of French royal parks, which were gated, fenced and closed to the public. ${ }^{2}$ The Corniche, Beirut's seafront promenade built during the French mandate, remains one of the few functioning, diverse and vibrant public spaces in the city (Nazzal and Chinder, 2018).

Despite its reputation as a thriving urban hub, following Lebanon's independence in 1948, modern Beirut started acquiring a chaotic physical appearance. The civil war militiamen took over public spaces between 1975 and 1990 and turned them into battlefields. This practice continued after the civil war when militiamen became part of successive governments, ${ }^{3}$ and institutionalised the division of state properties among themselves with the practice of political apportionment (muhasasa). Infighting between them exacerbated the city's haphazardness with their support for private encroachments on the public sphere shrinking public spaces. Since then, two processes have been the key drivers shaping the city's public spaces in modern times: modes of privatisation nourished by a laissez-faire market-led model of urban development; and political sectarian conflict (Monroe, 2016).

Reconstruction efforts in post-war Beirut were launched in 1992 and spearheaded by Solidere, a corporation that was owned by Lebanon's former Prime Minister the late Rafik Hariri, and now owned by his son, former Prime Minister Saad Hariri. While the corporation was cited by several planners and architects as an example of how the private sector has been more efficient than the state in improving urban spaces (Monroe, 2016), it is also being criticised by detractors and civil society activists for stripping Beirut's public spaces of their original meaning and function: to provide a habitable environment that reflects the city's cultural identity. ${ }^{4}$ The presence of private security guards across Beirut's Downtown and souks, rather than municipal police, render it a private, not a public space (Nazzal and Chinder, 2018).

Solidere's post-war reconstruction works reinvented the city's historic core - currently known as Beirut's Downtown and comprising the neighbourhoods of Bab Idriss, Mina el-Hosn, Wadi Abu Jamil and Al Borj Square (commonly known as Martyrs' Square), and others - making it into a separate enclave, abruptly severed from the rest of the city by a network of highways that constitute solid physical barriers (Ghandour and Fawaz, 2010). After the war ended, there was no work carried out by the state to reconnect people to their cities and hometowns and encourage social interactions in public spaces. $^{5}$

\footnotetext{
${ }^{2}$ Interview with Mohammad Ayoub, 7 July 2020, Beirut, Lebanon.

${ }^{3}$ Interview with Mohammad Ayoub, 7 July 2020, Beirut, Lebanon.

${ }^{4}$ lbid.

${ }^{5}$ Interview with Rony Jalkh, an expert and activist on placemaking and Director of Placemaking MENA NGO, conducted by Aseel Naamani on 7 July 2020 via Microsoft Teams.
} 
Tripoli, a 'forgotten' hub of public spaces and cultural heritage

Like Beirutis, Tripolitans' connectedness to their city has changed over the past decades. The civil war and successive armed clashes displaced people and destroyed many of the city's public spaces and green places. After the civil war ended in 1990 and the three-year armed clashes between Tabbaneh and Jabal Mohsen came to an end with a government-enforced 'security plan' in 2014, Tripoli did not see any government effort to put together a social development plan to revive a city that is rich in resources, and to allow for public spaces connecting disintegrated Tripolitans from the old and new parts with each other.

Situated approximately 85 kilometres North of Beirut, Tripoli is considered Lebanon's second capital, the economic hub of the North and Akkar governorates, and a centre of cultural heritage that is characterised by physical degradation. Years of armed conflict, coupled with decades of government neglect and underdevelopment (Louis Cardahi Foundation, 2004), have led to poverty, unemployment and a dilapidated urban fabric, compounded by high levels of environmental and acoustic pollution. Furthermore, conflicts, poverty and rural-urban migration led to internal movements of the richer inhabitants of old Tripoli to the newer parts, while the old city became host to rural and lower-income families from the poorer areas of Akkar, Minieh and Dennieh, in addition to Syrian workers and refugees (UN-Habitat, 20I6).

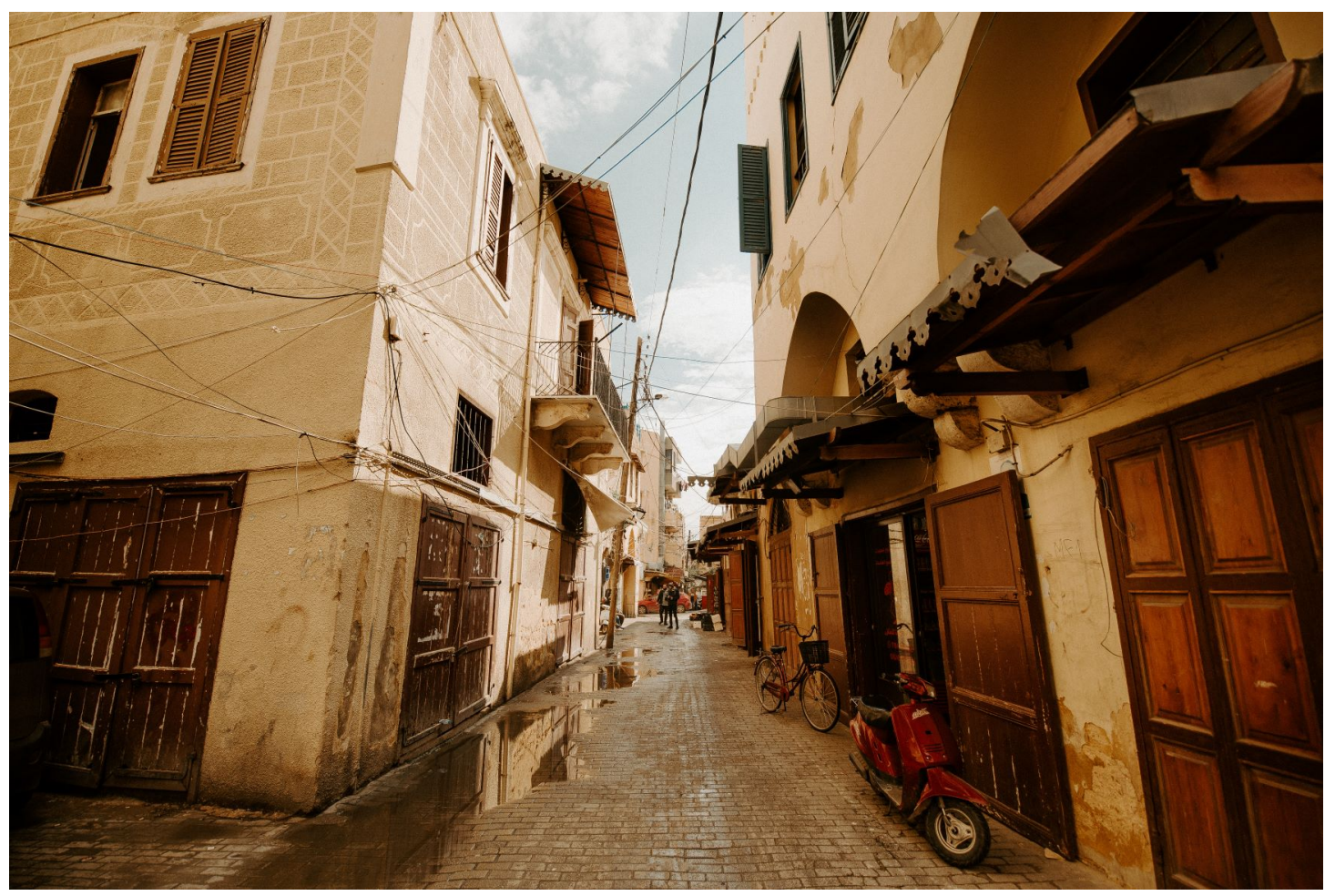

Figure I. Alleyways in Old Tripoli's neighbourhoods. Photo credits: Malek Haddad.

With several successive civilisations having left their cultural mark on Tripoli Hellenistic, Roman, Byzantine, Crusader, Mamluk, Ottoman - the city has a distinctive cultural and historical character. Its varied historical and cultural sites include Crusader and Mamluk towers in the al-Mina area, the St Gilles citadel, and a series of madrassas, 
hammams, khans and mosques in the historic core (Louis Cardahi Foundation, 2004), or what is today known as Old Tripoli (see Fig. I). More modern cultural edifices comprise of the uncompleted Maarad area, designed by Oscar Neimeyer, one of the most important figures in modern architecture. Construction of this monument, which began in the 1960s, was disrupted by the civil war, and remains unfinished. In contrast to Beirut, Tripoli's streets allow more breathing space with wider sidewalks, greenery and pedestrian spaces (Nazzal and Chinder, 2018).

The latest survey of Tripoli's historic monuments was carried out in 1995. It classified a total of 190 monuments - most of which are in Old Tripoli - and their immediate surrounding urban environments to be protected. These classifications were never enacted due to competing interests in ownership and the remaining areas being unprotected and thus open to modifications within specific limits set by the municipality (Information International, 200I).

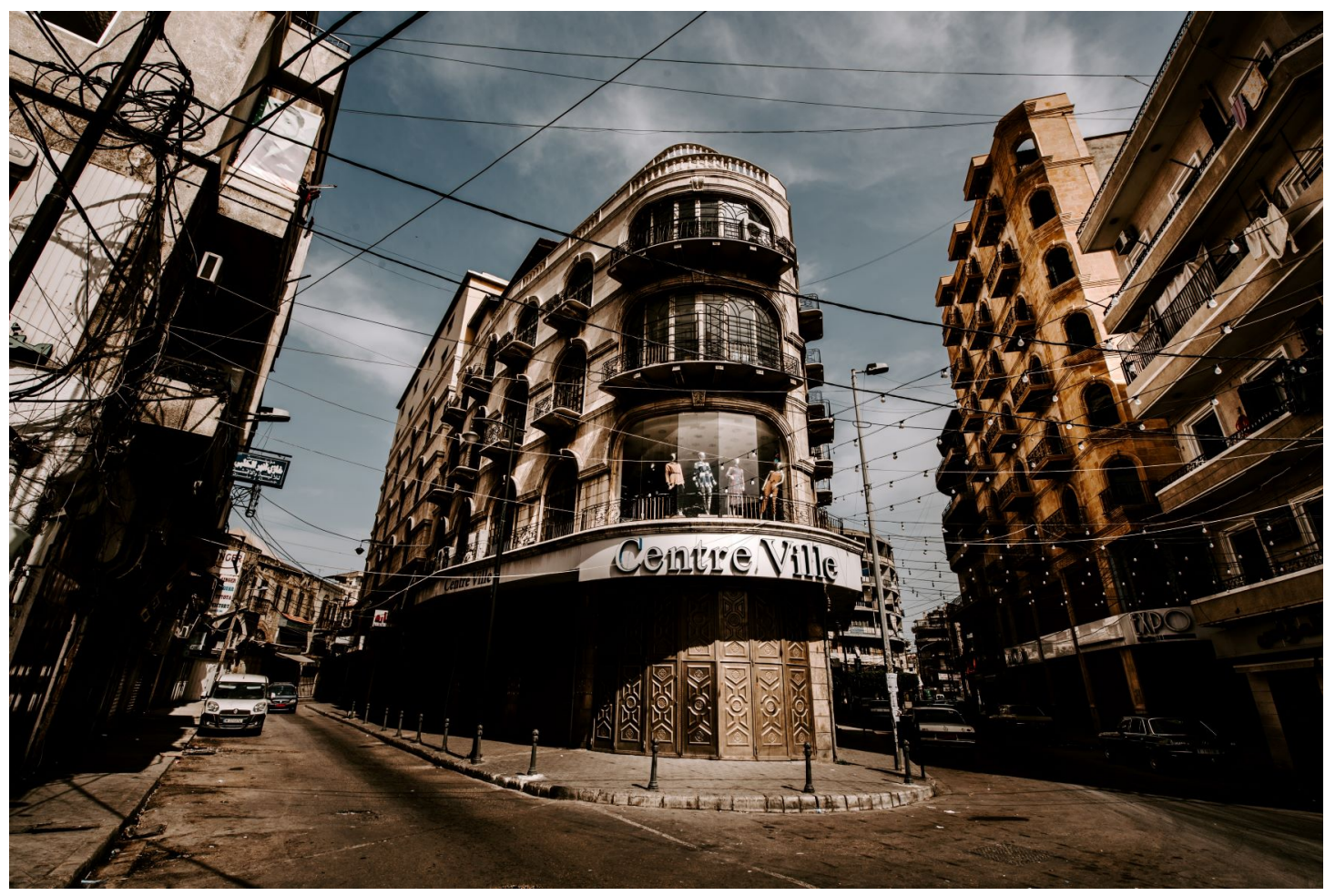

Figure 2. Buildings in the Old Tripoli downtown, al-Tall Square, built during the French colonial time. Photo credits: Malek Haddad.

Despite its abundance of cultural heritage, Tripoli is a fragile city characterised by physical degradation that is affected by poor urban planning and encroachments on public spaces. The old city lacks proper lighting and wastewater disposal. The Qadisha river, which already has low water levels, is polluted by household and vegetable market sewage outlets opening directly onto the river. Inadequate parking facilities, informal and illegal street vendors, and the absence of landscaped areas have contributed to the visual and environmental chaos of the city (Information International, 200I). Modern infrastructure projects and private resorts along Tripoli's coast have encroached on the 
maritime public properties, limiting free accessibility to the beach and posing dangers to the maritime ecosystem.

Several factors contribute to Tripoli's status as a fragile city despite several projects by UN-Habitat to support Tripoli municipality in reactivating its wide array of public spaces, including working with the municipality on providing data on the old city, profiling its neighbourhoods and supporting the development of a strategy on reactivating public spaces or guiding other civil society initiatives for similar interventions. Widespread poverty and marginalisation of the old city, according to the municipal council, limit their ability to ensure communities' acceptance for implementing its strategies. ${ }^{6}$

Stereotypes of Tripoli as a hub of instability have been perpetuated in reports across media, pinpointing the 20I I-20l4 clashes between Tabbaneh and Jabal Mohsen - two of the poorest neighbourhoods in Tripoli. As a result, inhabitants of both neighbourhoods have felt marginalised from the rest of the country and alienated by other Tripolitans residing in the new parts of the city, resulting in fragmentation of Tripoli's social fabric. The current centralised system adds to this sense of marginalisation, particularly in terms of lack of infrastructure and socio-economic development projects, and security. Implementing the law on decentralisation of administrative governance may offer a way to redress this centre-periphery imbalance, whereby municipalities would have greater autonomy in making decisions related to public services.

\section{Protesting encroachment on public spaces: the role of Lebanon's civic movements in reclaiming public spaces}

Democracy thrives in public spaces, and civic movements have almost always started there. While privatisation of public spaces was historically normalised, a newfound awareness arose with Lebanon's civic movements in 2008, and more recently with the October 2019 protests. Access to public spaces has not tended to be the primary focus of civic movements; however, "the way in which [civic movements] have used public spaces to come together, interact, and voice their opposition to government policies is by itself indicative of an elevated awareness as to the importance of public spaces in civic life". 7

Public spaces in Beirut and Tripoli have historically been a place of social, political and religious congregations, and they are usually influenced by what makes up a community's collective culture, including religion, geography, gender and age, as well as internal migration, colonialism and security surveillance. As such, religious institutions have historically been an integral part of public spaces. Mosques and churches were deliberately built very close to public spaces to attract people in. ${ }^{8}$ Villages still have public and communal spaces for social gatherings, which are normally at the centre of the village and accessible to most homes, aiming to foster social interactions, political debates and intellectual discussions. ${ }^{9}$

\footnotetext{
${ }^{6}$ Interview with Samer Chinder, Maryam Nazzal, and Wael Sinno, staff with UN Habitat Lebanon who have worked on public spaces in Beirut and Tripoli, Lebanon, conducted by Aseel Naamani on 6 July 2020 in Beirut, Lebanon.

${ }^{7}$ Interview with Rony Jalkh, 7 July 2020, Beirut, Lebanon.

${ }^{8}$ Interview with Mohammad Ayoub, 7 July 2020, Beirut, Lebanon.

${ }^{9}$ lbid.
} 
Squares in Beirut and Tripoli assumed civic meaning in the early twentieth century with nationalist revolts against the colonial rulers. Such squares were seen to be "consecrated by the blood of locals" who clashed with the colonial forces to demand independence, or by the execution of national leaders by colonial forces (Rabbat, 20I2). Thus, such squares were given names that commemorated martyrs (for example, alBorj Square in modern Beirut Downtown was renamed Martyrs' Square in 1916) or celebrated national leaders (such as Riad al-Solh and Beshara al-Khoury squares in Beirut, and Abdelhamid Karami Square in Tripoli, commonly known as al-Nour Square). After the country gained independence in 1948, many of Lebanon's squares were used as places for national celebrations and contestation alike.

The 1990s to mid-2000s - the period comprising the end of the civil war and the start of the Syria hegemony over Lebanon - saw less political and civic mobilisation in public spaces (Bray-Collins, 2016). During this period, the mobility of middle- and upper-class youth, who grew up without direct experience of the civil war, transcended the city's political and sectarian considerations defining its neighbourhoods' geography and seemed to be "motivated by cultural and consumer sensibilities and leisure practices" (Monroe, 2016) rather than by political and sectarian positioning. Open and accessible public spaces, being scarce in Lebanon, were unavailable to such youth and such interactions were made in private or closed realms, including private and public schools and universities.

For less privileged youth, mobility was significantly defined by the extent to which they have the financial capital to move outside their neighbourhoods and around the country. For this reason, their mobility was driven by the location of their education or workplaces rather than by recreational activities. In a way, universities and workplaces, while not gaining the status of a public space, did function as open social settings that allowed for free communication, without the shackles of censorship about matters concerning culture, society, politics or any subject of public concern. As such, public life retreated from urban public spaces to private ones, and civil society and youth political life could only be conducted in private realms, most notably universities, which generally allowed for vibrant political activism with the presence of youth wings of political parties on-campus, even those that were banned from actual political life and executive power at the time. Democratic life was manifested at its best and elections for student bodies were the norm, organised by youth wings of political parties and independent activists. Political and civic activism thrived; although it was away from its natural places - state institutions and public spaces - it gave rise to a vibrant civil society during the early 2000s.

As a result, civic and political movements gained momentum and used urban public spaces to organise demonstrations that were triggered by political and economic grievances against the political elite. Such mass movements, which started with the 2005 protests following the assassination of former Prime Minister Rafik Hariri, included the 2015 \#YouStink protests in response to the solid waste crisis (Bray-Collins, 2016) and the most recent 'October Protests' in 2019.

Civic movements contributing to an elevated popular awareness on public spaces

Public spaces are not only congregation spaces; they are streets, open public spaces, public facilities and markets, which provide the setting of community life and livelihood of the urban poor (UN-Habitat, 2018). Their importance lies in their function of 
providing a habitable environment that reflects the society's cultural identity, ${ }^{10}$ and their use has been central to civil society movements since $2015^{11}{ }^{12}$.

People's inalienable right to access public spaces captured the general public's attention following the 2015 protests in Downtown Beirut when the head of the Beirut Traders Association said that the presence of regular protests in Beirut's Downtown was "cheapening" the area (Battah, 20I5). His statement encapsulated an entitlement to that part of Beirut and served to reinforce the perception that the average citizen was not welcome. In response, protesters gathered in Downtown Beirut's Riad al-Solh Square to set up a flea market. They satirically named it 'Souk Abou Rakhousa', which is Lebanese slang for 'the cheap market'. For the generation who lived in pre-war Beirut, the market was reminiscent of a time when the public felt the city belonged to them.

Since then, young people have increasingly been voicing their opinions, via blogs and social media, as well as by actively mobilising in groups and networks, with the aim of making their cities more liveable. Nonetheless, such groups are often fragmented with differing understandings of, or priorities related to, public spaces. Some favour visual beautification in their work, while others are disseminating a critical understanding of public spaces according to Lebanese laws and initiating a debate about reclaiming them. One example is the campaign led by NAHNOO, and launched in $201 \mathrm{I}$, to reopen Horsh Beirut - the last and largest green space in Beirut, which has been closed to the public since the civil war. The campaign aimed to re-establish it as a public space for all and to reintegrate it into the city's daily life, transforming it into a venue for fostering social interaction between individuals and across communities. Years of lobbying politicians, ministries and Beirut municipality, as well as outreach and awareness-raising activities, culminated in el-Horsh's reopening in September 20I5, initially on Sundays only, until it finally reopened fully to the public in July 2017.

The campaign, however, was met with pushback from authorities that "develop narratives, strategies and mechanisms to naturalise their dominance over the city and its public spaces, and their exclusion of ordinary dwellers, especially poor and marginalised groups" (Dikeç, 2002). In that sense, the political elite and their clientelist networks had used excuses such as building public hospitals and widening roads to justify

encroachments on el-Horsh. Additionally, a major obstacle to civic movements is counter-lobbying by the private sector who are generally well connected to the elite. Clientelism, nepotism and corruption, which have allowed such encroachments for years, remain a main target of civic campaigns and a key sticking point. The el-Horsh campaign was no exception and activists relied on messaging and communications when reaching out to decision-makers and establishing working relations, while raising awareness to put public pressure on them. ${ }^{13}$

Other claims on spaces are organic and uncoordinated, such as cases of children and youth in Beirut suburbs claiming empty lots as recreational spaces, where surrounding

\footnotetext{
${ }^{10}$ Interview with Mohammad Ayoub, 7 July 2020, Beirut, Lebanon.

"Interview with Abir Saksouk-Sasso, architect, urban planner, and researcher with Public Works Studio, a Lebanese research and design studio on urban and public issues in Lebanon, conducted by Ruth Simpson on 15 July 2020 via Microsoft Teams..

12 Interview with Jessica Chemali, Deputy Executive Director of Legal Agenda, a Pan-Arab NGO specialized in research and advocacy on law and society, conducted by Ruth Simpson on 17 July 2020 via WhatsApp.

${ }^{13}$ Interview with Mohammad Ayoub, 7 July 2020, Beirut, Lebanon.
} 
neighbourhoods share these spaces for picnics, sports and other leisure activities. However, these are under threat. An aerial mapping of these lots showed that $85 \%$ of them had been encroached on by private real estate in recent years, putting immense pressure on communal and public spaces. ${ }^{14}$ Such informal spaces offer marginalised children and youth, including refugees and migrant workers, with no access to private youth clubs or other recreational spaces a rare opportunity for interaction and developing social interactions.

Demands on, access to and use of urban public spaces differ based on gender, age, socio-economic status and other social and identity markers. Discourse around the intersection between gender and public space in Lebanon is growing in academic literature and includes projects on gender and women's engagement in urban planning and reclaiming public spaces, among other initiatives (Batakji, 2020; University of Sheffield, 2020). Such discourse is also important in social movements, especially with the frontline role women played in the October movement. For example, women in the Sassine area of Beirut have highlighted street lighting (for safety) and pedestrian accessibility (for walking in daylight hours) as areas of concern ${ }^{15}$ (Melki, 2019).

\section{The October movement - an opportunity to reclaim public spaces and a catalyst for interaction?}

One of the gains of the October movement is that it brought debates out of the private realm of universities and intellectual circles and into public spaces, and fostered interactions among the cities' diverse social fabric (Fawaz and Serhan, 2020). Before the October movement, many protestors would not access these areas. More marginalised citizens, including those who would be stigmatised as homeless, substance abusers, 'hooligans' or 'outsiders', were able to join in reclaiming many of the public spaces through arts, culture and dialogue. They contribute to the historical and cultural discourse of the country through community artwork (Naamani, 2019). Arts, culture and dialogue successfully connected excluded groups to the remaining constituents of the cities' social fabric and contributed to rebuilding such groups' self-confidence to reclaim public spaces that have long been abandoned or made accessible only to the social elite. On 17 October 2019, people across Lebanon took to the streets in massive popular demonstrations sparked by an economic crisis (see Fig. 3). Citizens from all walks of life gathered in public spaces in Beirut, Tripoli and other cities, and in peripheral villages that normally saw little civic movements. Protesters (re)discovered previously exclusive spaces, and public spaces embodied a "new concrete meaning" ${ }^{16}$ for those who participated, the young people especially, and became catalysts for interaction, political discussions and informal learning.

\footnotetext{
${ }^{14}$ Interview with Abir Saksouk-Sasso, 15 July 2020 via Microsoft Teams.

15 This data was collected prior to the Beirut seaport explosion.

${ }^{16}$ Interview with Jessica Chemali, 17 July 2020 via WhatsApp.
} 


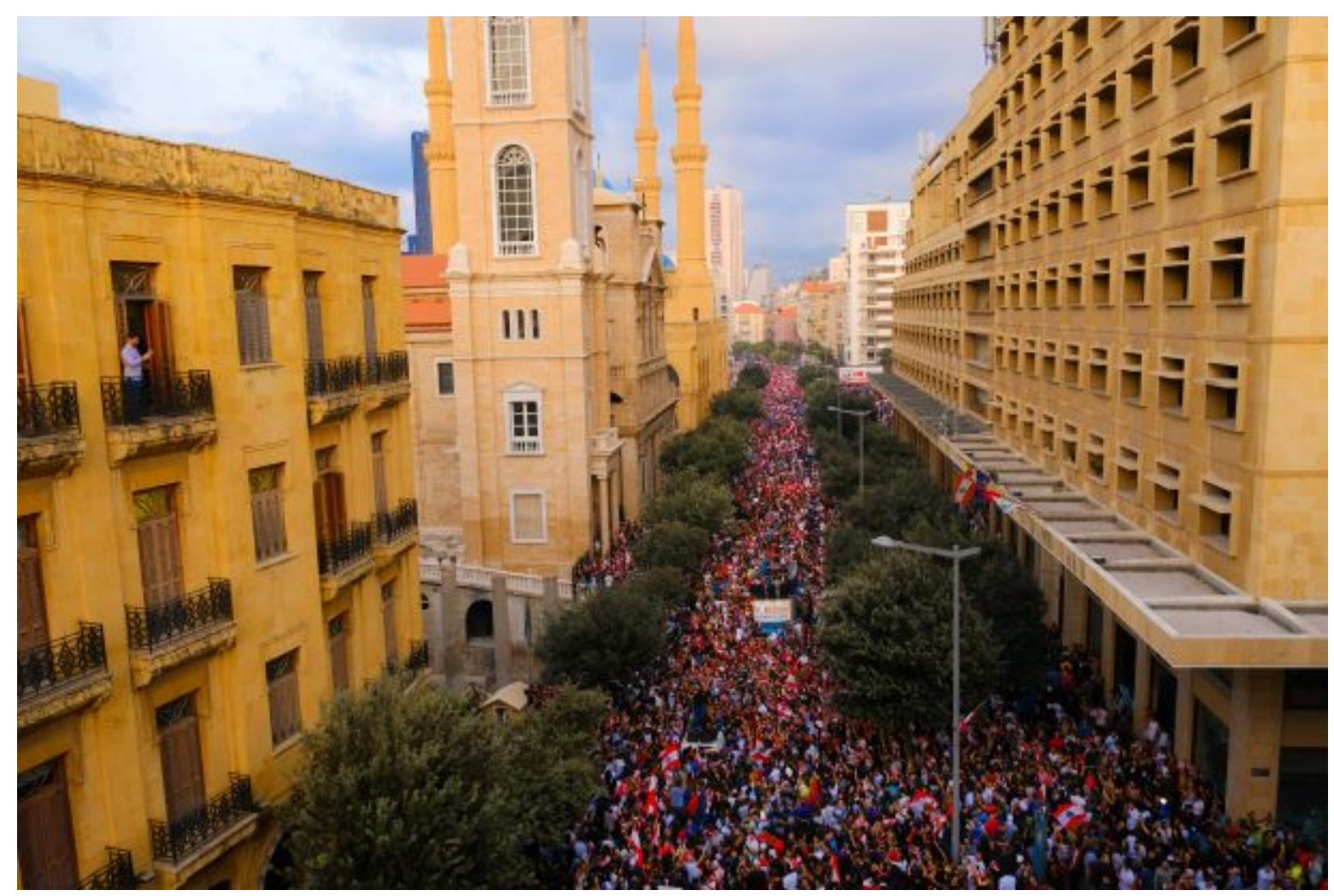

Figure 3. People taking to the streets in Downtown Beirut, October 2019.

Photo credits: Ali Hamouch.

Unlike in previous demonstrations, mounting economic grievances, precipitated by Lebanon's severe economic crisis, explain why the 2019 protests were able to garner a sustained presence in main public squares from across geographical, sectarian and political divides. While activist groups perceive economic demands as the driving factor behind their movement, they believe that, once rights are attained and grievances resolved, this will lead to achieving higher gains, including reclamation of public spaces. ${ }^{17}$ In previous demonstrations, Downtown Beirut would return to its usual high-end restaurants and shopping and entertainment centres, but the October protests were different, as protestors continuously filled its spaces and organised cultural activities and political debates (Fawaz and Serhan, 2020). In that sense, protestors transformed such public venues into revived platforms for debate, echoing across social media with the hashtag \#ReclaimingThePublicSpace. ${ }^{18}$

Other claims on public spaces were symbolic, with protestors blocking the highways that serve as arteries in and out of main cities across Lebanon. Some even set up a living room and others organised yoga classes and football games on the highway connecting Hamra to Achrafieh, aiming to make the clear statement that these spaces belong to them.

\footnotetext{
${ }^{17}$ Interview with Samer Chinder, Maryam Nazzal and Wael Sinno, 6 July 2020 in Beirut, Lebanon.

${ }^{18}$ Ibid.
} 


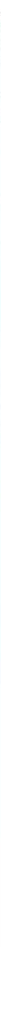

Figure 4. A public discussion session between protestors in Downtown Beirut, October 2019. Photo credits: Aseel Naamani.

Arts were also used as a means of expression by protestors, as acts of transgression and as counter-hegemony (Fawaz and Serhan, 2020). In the streets of Downtown Beirut, one would pass graffiti artwork (as in Fig. 5) and caricatures portraying the elite's detachment from the daily struggles of the Lebanese people.

Across cities, artists would congregate and create in reclaimed spaces. From the abandoned Grand Theatre in Downtown Beirut, Soprano singer Mona Hallab, from Tripoli, and her friend shot a video showing Hallab singing the lyrics of a song written by another protestor, praising the newfound unity among Lebanese (see Fig. 6).

"I've always heard of the Grand Theatre, and as a citizen and soprano singer, it has always been upsetting for me that Lebanon is one of the very few Arab countries that doesn't have a functional opera house. We wanted to make a statement that some places belong to the people and should go back to the people; this is one of our legitimate rights. This is why going in there and singing, even without audience was a small but very meaningful victory to me."19

\footnotetext{
${ }^{19}$ Interview with Mona Hallab, artist and activist from Tripoli who resides in Beirut, Lebanon, conducted by Aseel Naamani on 3 November 2019 in Beirut, Lebanon.
} 


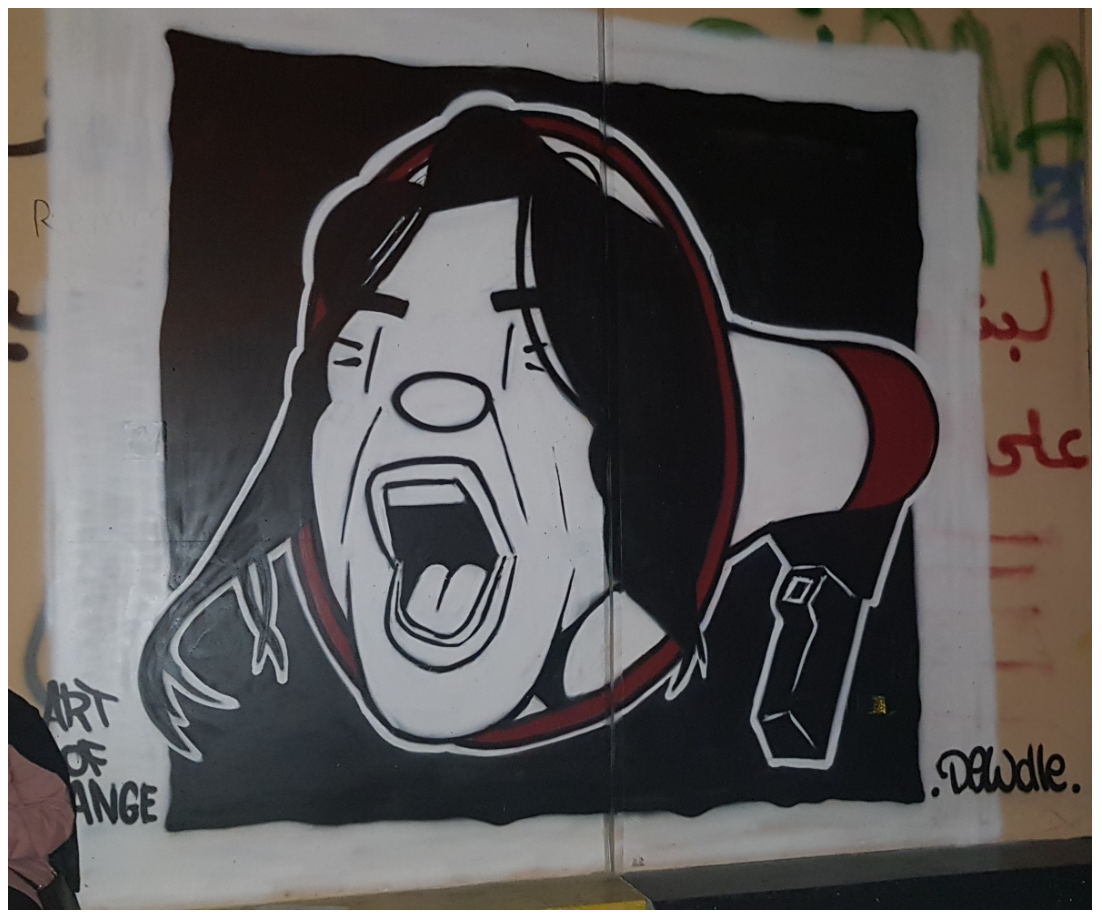

Figure 5. Graffiti drawing in Downtown Beirut during the October protests. Photo credits: Aseel Naamani.

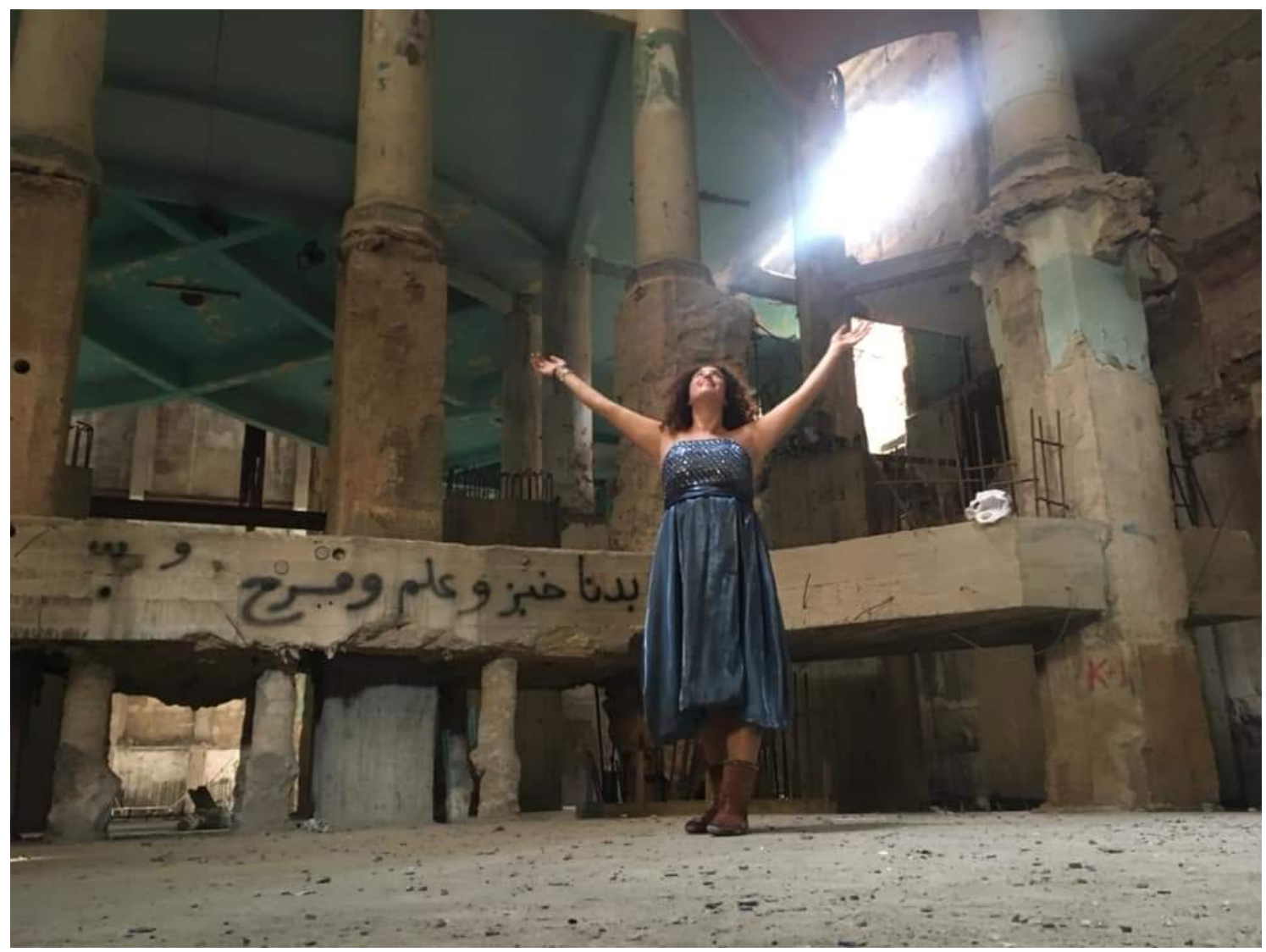

Figure 6. Hallab singing from inside the Grand Theatre, October 2019. Photo credits: Marie-Rose Osta. 
Tripoli was named 'Arous el-Thawra' (Arabic for 'Bride of the Revolution') because of the scale, vibrancy and sustained nature of the demonstrations. There were nightly events with DJs and famous Lebanese singers alongside tents that hosted debates and discussions, child-friendly activities and a communal kitchen. By shedding its hitherto conservative persona, and with its public spaces coming alive, Tripoli was challenging the idea of the exclusivity of civic movements, culture and arts to Beirut.

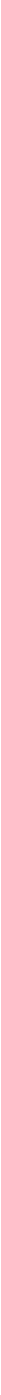

Figure 7. Tripoli protests in al-Nour Square, October 2019. Photo credits: Malek Haddad.

Youth groups in Tripoli transformed the use of al-Nour Square following approaches embedded in placemaking (see Fig. 7). They worked in a participatory manner with other protestors to identify the objective of the new public space and test its function before setting up their tents and activities. This concept is based on the premise that any change introduced to a public space is temporary and should regularly be tested by the communities using it, and if it stops serving its objective then it should be remodelled. Youth protestors became more aware of laws governing and defining public spaces, which was a cornerstone in their understanding and respect of their essential 
function: a function that implies enabling safe and inclusive access to all. Youth in Tripoli used this and other placemaking concepts to keep al-Nour Square vibrant with protestors. $^{20}$

Through the October movement, young people transformed public venues into platforms where dialogue and arts were used as tools of empowerment to overcome confessional barriers. They organised public debate sessions to make a statement that these venues belong to them and their stories (Naamani, 2019). Such initiatives showed an unprecedented level of awareness by protestors of the use of peaceful methods and the adoption of a more critical perspective towards conflicts, enabling them to envision peaceful ways to play a valued socio-political role.

\section{Post-October 2019, economic crisis, COVID-19 and implications for inclusive public spaces and social connections}

Nearly two years from the beginning of the nationwide protests, Lebanon is grappling with economic, fiscal and political crises, aggravated by the onset of a public health emergency, the COVID-I 9 pandemic since February 2020, and the ramifications of the Beirut seaport blast that rocked the country on 4 August 2020. The country went into a nationwide lockdown in mid-March, which has eased gradually and intermittently since then. The healthcare emergency (both the fear of the pandemic and the lockdown measures) had significant impacts on the dynamics created during the October protests in relation to public spaces on three main fronts. First, COVID- 19 restrictions have limited access to public spaces, and have been used to act against protests and securitise public spaces; second, the intersecting economic and COVID-19 crises stalled the protests; and, finally, lack of public spaces and infrastructure in urban centres impacts the ability for safe social distancing (Nobajas et al., 2020).

While it is widely agreed that decisive action was needed to respond to the pandemic, many also suspect that COVID-19 and the declaration of a State of Emergency in the capital following the Beirut explosion were used as pretexts for dismantling the protest infrastructure in public spaces set up in October 2019. The presence of security forces and restrictions imposed during the pandemic provided an 'excuse' to clear protests, carry out raids and push people from the streets ${ }^{21}$ (Oxford Analytica, 2020).

COVID-19, coupled with the economic crisis, has stalled the progress made in Tripoli in reclaiming public spaces. ${ }^{22}$ Despite the government lockdown, people have been taking to the streets angered by the severe economic downturn and the slow response of the government to provide both immediate and long-term solutions. The country's intersecting crises unravelled in the already neglected Tripoli, and manifested in attacks on banks and violent clashes between protestors and the Lebanese Army in al-Nour Square, which only months before had been the scene of peaceful demonstrations. "The downward spiralling of the security situation in Tripoli caused the perception by city inhabitants that Tripoli is left by the security forces to deal with such incidents 'on its

\footnotetext{
${ }^{20}$ Interview with Rony Jalkh, 7 July 2020 via Microsoft Teams.

${ }^{21}$ Interview with Mona Harb, Professor of Urban Studies and Politics at the American University of Beirut (AUB), conducted by Ruth Simpson on 30 October 2020 via Microsoft Teams.

${ }^{22}$ Interview with Samer Chinder, Maryam Nazzal and Wael Sinno 6 July 2020 in Beirut, Lebanon.
} 
own.." ${ }^{23}$ For this reason, and the COVID-related lockdown, al-Nour Square became empty of protestors and normal life.

Pre-pandemic there were more opportunities for diverse interactions among different refugee groups and between the refugee and Lebanese marginalised communities in informal recreational spaces in Beirut suburbs. ${ }^{24}$ COVID-19 restrictions severely limited these opportunities for recreation and socialising, not simply due to the limits on public gathering, but because of increased fear by refugees and migrant workers of moving in public spaces during the pandemic. ${ }^{25}$ There have been incidents of verbal and physical harassment of refugees and other non-nationals, related to rising stigma related to the pandemic (Fouad et al., 202I), as well as curfews being applied in a discriminatory manner, further curbing use of public spaces (Human Rights Watch, 2020).

While COVID-19 measures are largely seen as curbing protests, there are some examples of such measures sparking protests. As restrictions were being lifted, some activists questioned why restaurants were opened before public parks and why private beach clubs opened before public beaches. This resulted in spontaneous protests with groups going to the sea, first in Tripoli and then elsewhere to swim in public beaches. ${ }^{26}$ Thus, COVID-19 restrictions have underscored the importance of public spaces serving the public good, rather than private gain.

Although in the short term the COVID-19 crisis has limited the mass movements to reclaim public spaces, it seems unable to stem the tide of shared awareness and belonging developed in the October movement. The deepening economic crisis is further constraining people's ability to access private areas for socialising and entertainment and driving them to public spaces, such as public beaches and campsites. Elites have thus regained some (public) ground contested during and through the uprising through public health measures.

\section{Shared spaces: urban public spaces as venues for peacebuilding}

The October movement and COVID- 19 underline the imperative to rethink public spaces and provide communities with open and inclusive places to interact and communicate freely. The public square should not function as the city's gateway for its elite but should provide opportunities to engage in political, social and cultural debates, and allow people to reimagine and co-create public spaces in a participatory way. ${ }^{27}$ In the context of concurrent economic, political and health crises, finding platforms that allow communities to get together and reactivate public spaces requires a considered approach, which entails addressing and analysing the specific fragility and safety factors in each context. As a starting point, it is crucial to acknowledge the restrictions that the COVID-I 9 pandemic has placed on using public spaces, and the "best way to approach public spaces now is to think small-scale, in a sense that community members gather and look for ways to make use of and renovate the available public spaces in their

\footnotetext{
23 lbid.

${ }^{24}$ Interview with Abir Saksouk-Sasso, 15 July 2020 via Microsoft Teams.

${ }^{25}$ Interview with Mona Harb, 30 October 2020 via Microsoft Teams.

${ }^{26}$ Interview with Abir Saksouk-Sasso, 15 July 2020 via Microsoft Teams.

${ }^{27}$ Interview with Rony Jalkh, 7 July 2020 via Microsoft Teams.
} 
neighbourhoods". ${ }^{28}$ Such an approach entails in-depth level of working with communities to help them identify, understand and analyse their needs.

Public spaces and the urban environment can be a prism through which to view and understand peacebuilding processes in the city space and how urban conditions can facilitate or hinder the construction and maintenance of peace (Björkdahl, 20I3). In that sense, peacebuilding processes need to work with all constituents of cities' social fabrics, and to better address, analyse and mitigate tensions and spatial practices related to the distinctive culture, religious sects and social class of communities in diverse cities such as Beirut and Tripoli.

Public spaces can provide unparalleled spaces for peacebuilding, renegotiating relationships and reconciliation. ${ }^{29}$ They provide fluid and informal spaces to engage diverse communities, including those traditionally marginalised. They can be used as spaces for inclusive dialogue, exchanging ideas, discussing concerns and reaching joint solutions. Where physical gathering presents a challenge in the COVID-19 era, using GPS and aerial mapping can help overcome the challenges of on-the-ground physical mapping and engagement during a pandemic. Here it is possible to draw from International Alert's GPS mapping approach to urban peacebuilding (International Alert, 2017).

In Tripoli, International Alert worked with a local organisation to support young men and women from different neighbourhoods in mapping historical, cultural and touristic landmarks in their city. Youth were trained on using GPS technology for mapping around a hundred historical and religious landmarks, schools, pharmacies, restaurants, shops, etc., which were later added to Google Maps. The initiative helped youth, across conflict divides, to regain a sense of pride in and belonging to their city. This initiative is among several that work with public spaces as venues for peacebuilding.

Although such initiatives are instrumental in fostering social interactions across divides, as they bring youth from different parts of Tripoli to work together, sustainable programmes are needed. Age, class, sectarian and political differences continue to act as flashpoints of division (Al-Masri, Abla and Hassan, 2020). Despite the display of national unity in al-Nour Square, spatial connections within the city are weak. Class differences are particularly stark in Tripoli and they affect motivation to join protests, the nature of participation and the type of direct actions preferred and carried out.

The current crisis and the increased citizen interest in public affairs bring opportunities for the movement to push for shifting the discussion from political infighting within patron-clientelist frameworks to reformist and inclusive processes. This presents an opportunity to support processes for facilitating collective decision-making or deliberative democracy, such as Citizens' Assemblies at municipal level, including in urban centres such as Beirut and Tripoli (Al-Masri, Abla and Hassan, 2020). This includes bringing together a range of participants from diverse political, regional, socioeconomic, gender and other backgrounds to discuss key issues, such as reimagining public spaces, and develop joint actions and visions. Municipalities are one of the key partners in this process, and the best approach to transfer knowledge to them is "learning-by-doing". 30

\footnotetext{
28 Ibid.

${ }^{29}$ Interview with Abir Saksouk-Sasso, 15 July 2020 via Microsoft Teams.

${ }^{30}$ Interview with Rony Jalkh, 7 July 2020 via Microsoft Teams.
} 
Decentralisation offers an opportunity to engage municipalities, a main stakeholder in peacebuilding efforts related to public spaces. Such engagement is not without challenges, given the lack of municipal financial and technical resources for urban planning, ${ }^{31}$ and efforts should be balanced with bottom-up, organic approaches to reimagining public spaces. For example, renovation works of a community football playground in a Tripoli neighbourhood where the main users, including children and youth, and secondary users, including adult men (and to a lesser extent adult women due to social and cultural norms in such a context around women's participation in public sports), did not participate in imagining and designing the space resulted in the exclusion of their needs, as the high-walled and gated space did not provide a sense of safety for them to freely make use of it. ${ }^{32}$ The cases of informal football fields and other social gathering places in Beirut and Tripoli (March Lebanon, 2020) and the reclaiming of public spaces in the October 2019 movement show that it is the informality or transgression that allows space for genuinely inclusive and open interaction between different communities. ${ }^{33}$ Therefore, efforts need to be both formal and informal, and link grassroots initiatives with national-scale efforts in planning to reclaim public urban spaces.

The post-October 2019 context presents an opportunity to build a community of practice on evolving dynamics and peacebuilding trends, including public spaces (AlMasri, Abla and Hassan, 2020). Civil society organisations, and especially youth networks, represent key agents for advocacy and coalition-building across communities around reclaiming public spaces. ${ }^{34}$ Acknowledging that "different areas of expertise have a role in designing safe and inclusive public spaces including architects, urban planners, social scientists, experts on gender and child safety, municipal police, local CSOs, representatives of political parties, schools, educators, mosques and churches, dispensaries, etc.", ${ }^{35}$ organisations are now adopting this integrated approach that brings them together and engages them throughout the design and implementation phases.

\section{Conclusion: Reconstructing public spaces as a public good}

Issues of public space have increasingly been at the heart of social movements and calls for reform, as seen most recently in the October movement, where protests reclaimed new spaces. These movements reimagined and transformed people's relationship with public spaces, raised awareness on their rights of access to public spaces and reaffirmed their commitment to reclaim those rights. "Collectivities come together to embody an alternative political imaginary, one where being together is based on the shared aspirations of a life in dignity and mutual respect" (Fawaz and Serhan, 2020). In the context of clientelist networks, which are invested in encroachments on public spaces, and considering the broader context of Lebanon's sectarian power-sharing system, the reality is that such reclamation is a lengthy process, fraught with challenges.

\footnotetext{
${ }^{31}$ Interview with Mona Harb, 30 October 2020 via Microsoft Teams.

${ }^{32}$ Interview with Rony Jalkh, 7 July 2020 via Microsoft Teams.

${ }^{33}$ Interview with Abir Saksouk-Sasso, 15 July 2020 via Microsoft Teams.

${ }^{34}$ Interview with Jessica Chemali, 17 July 2020 via WhatsApp.

${ }^{35}$ Interview with Rony Jalkh, 7 July 2020 via Microsoft Teams.
} 
Many believe that it is too early to claim that public spaces are fully reclaimed; however, their use was certainly rediscovered by the people. ${ }^{36}$ The lack of vision, resources and capacities for urban planning has contributed to the prioritisation of public spaces by local authorities; coupled with the economic crisis, it has the potential to threaten the gains of the movement and the sustainability of such shared spaces against encroachment.

There is little doubt that Lebanon's past conflicts have disrupted people's connectedness to public spaces, and the political obstacles to reclaiming public spaces loom large. However, what the October movement has succeeded in doing is giving back to public spaces their true meaning and function of offering essential opportunities for diverse interaction across class, political, social, generational and gender divides. To build on these advances, public spaces need to be understood as a public good and as a crucial vector for inclusive engagement and peacebuilding. To both reframe and reclaim public spaces as a public good, capitalising on gains made in the October 2019 movement, which can lay the grounds for peacebuilding, it is critical to invest in maintaining safe, inclusive and openly accessible public spaces. This necessitates a shared vision for how these spaces can be used by people to cultivate a shared sense of belonging with the space through community-led social, cultural and economic activities. It is crucial that municipalities are actively engaged in planning and coordinating the use of such spaces. This requires resources, technical capacities for mapping and planning spaces over the long term, as well as political will. ${ }^{37}$

\section{References}

Abou-Hodeib, T. (201 I). 'Taste and class in late Ottoman Beirut', International Journal of Middle East Studies, 43(3), pp. 475-492. Available at: www.jstor.org/stable/23017313 (Accessed: 23 July 2020)

Al-Masri, M., Abla, Z. and Hassan, R. (2020). Envisioning and contesting a new Lebanon? Actors, issues and dynamics, International Alert [online]. Available at: https://www.internationalalert.org/publications/envisioning-and-contesting-new-lebanon-october-protests (Accessed: I September 2020)

Altpeter, C. (2016). Peacebuilding in cities: Building safe, inclusive and resilient urban spaces [online]. Available at: https://www.ipinst.org/wp-content/uploads/2015/04/ief-brief-2016.pdf (Accessed: I July 2020)

Batakji, R. (2020). 'On creating and reclaiming public spaces', Lebanese American University, 7 January [online]. Available at: https://news.lau.edu.lb/2020/on-creating-and-reclaimingpublic-spaces.php (Accessed: 23 July 202I)

Battah, H. (2015). 'Abou Rakhousa and the politics of poverty', Bold Magazine, October [online]. Available at: https://bit.ly/3hrVGpo (Accessed: 6 July 2020)

Biennale Spazio Pubblico (20/3). The Charter of Public Space [online]. Available at: http://www.biennalespaziopubblico.it/outputs/the-charter-of-public-space/ (Accessed: 23 July 202I)

Björkdahl, A. (20I3). 'Urban peacebuilding', Peacebuilding, I (2) [online]. Available at: 10.1080/2। 647259.2013.783254 (Accessed: 5 November 2020)

\footnotetext{
${ }^{36}$ Interview with Samer Chinder, Maryam Nazzal and Wael Sinno, 6 July 2020 in Beirut, Lebanon.

${ }^{37}$ Interview with Mona Harb, 30 October 2020 via Microsoft Teams.
} 
Bollens, S. (2006) 'Urban planning and peace building', Progress in Planning[online]. Available at: 10.1016/j.progress.2006.07.00I (Accessed: 29 October 2020)

Bray-Collins, E. (2016) 'Sectarianism from below: Youth politics in post-war Lebanon' [online]. Available at: https://tspace.library.utoronto.ca/bitstream/I807/76345/3/BrayCollins Elinor F 2016II PhD thesis.pdf (Accessed: 23 July 202I)

Dikeç, M. (2002). 'Police, politics, and the right to the city', Geojournal, 58(2/3) [online]. Available at: www.jstor.org/stable/4 I I 47755 (Accessed: I 8 July 2020)

Fouad, F.M., McCall, S.J., Ayoub, H., Abu-Raddad, L.J. and Mumtaz, G.R. (202I). 'Vulnerability of Syrian refugees in Lebanon to COVID- 19: Quantitative insights', Conflict and Health [online]. Available at: https://conflictandhealth.biomedcentral.com/track/pdf/I0.1 |86/s/303I-02I00349-6.pdf (Accessed: 23 July 202I)

Fawaz, L.T. (1983). Merchants and migrants in nineteenth-century Beirut. Cambridge, MA: Harvard University Press.

Fawaz, M. and Serhan, I. (2020). 'Urban revolutions: Lebanon's October 2019 uprising', International Journal of Urban and Regional Research [online]. Available at: https://www.ijurr.org/spotlight-on/urban-revolts/urban-revolutions-lebanons-october-2019uprising/ (Accessed: 30 October 2020)

Ghandour, M. and Fawaz, M. (2010). 'Spatial erasure: Reconstruction projects in Beirut', ArteEast Quarterly, Spring [online]. Available at: https://lib.dr.iastate.edu/cgi/viewcontent.cgi?article $=1047 \&$ context $=$ arch_pubs (Accessed: 26 October 2020)

Human Rights Watch (2020). Lebanon: Refugees at risk in COVID-19 response discrimination risks harming Syrians, Lebanese alike [online]. Available at: https://www.hrw.org/news/2020/04/02/lebanon-refugees-risk-covid-19-response (Accessed: 29 July 2020)

Information International (200I). Stakeholder Analysis and Social Assessment for the Proposed Cultural Heritage and Tourism Development Project [online]. Available at: https://charbelnahas.org/? $p=185$ (Accessed: 5 July 2020)

International Alert (2017). Young people put Tripoli on the map [online]. Available at: https://www.international-alert.org/stories/young-people-put-tripoli-map (Accessed: 20 July 2020) 
Jehl, D. (1997). 'Under Beirut's rubble, remnants of 5,000 years of civilization', The New York Times [online]. Available at: https://nyti.ms/3fUYCuf (Accessed: 20 July 2020)

Kanafani, S. (2017). 'On deference and benevolence: The politics of parking in Beirut', The Arab Studies Journal, 25(I) [online]. Available at: https://www.jstor.org/stable/26528956 (Accessed: 23 July 202I)

Louis Cardahi Foundation (2004). The Phoenicians' route [online]. Available at: https://lcf.lau.edu.lb/images/phoenician-tripoli.pdf (Accessed: I 8 July 2020)

March Lebanon (2020). Arts on the streets, a message of peace and unity [online]. Available at: https://bit.ly/32LIdmU (Accessed: 23 July 2020)

Melki, S. (2019). 'Urban development in Beirut: Gender and space', Middle East Topics \& Arguments [online]. Available at: https://archiv.ub.uni-marburg.de/ep/0003/article/view/7928 (Accessed: 23 July 202I)

Monroe, K. (2016). The insecure city: Space, power, and mobility in Beirut. New Brunswick, New Jersey; London: Rutgers University Press [online]. Available at: www.jstor.org/stable/j.cttlb67ws4 (Accessed: 23 July 2020)

Naamani, A. (2019). Lebanese youth are reclaiming public spaces with arts and dialogue, International Alert [online]. Available at: https://bit.ly/39mKveG (Accessed: 5 July 2020)

Nazzal, M. and Chinder, S. (2018). 'Lebanon cities' public spaces', The Journal of Public Space, 3(I) [online]. Available at: https://doi.org// 0.5204/jps.v3il.323 (Accessed: 6 July 2020)

Nobajas, A., Casas, J.G., Agustí, P. and Peacock, A. (2020). Lack of sufficient public space can limit the effectiveness of COVID-19's social distancing measures [online]. Available at: https://www.medrxiv.org/content/I0.I I0I/2020.06.07.20124982vI.full.pdf (Accessed: I November 2020)

Oxford Analytica (2020).Securitised Middle East COVID-19 responses raise risks, July [online]. Available at: https://dailybrief.oxan.com/Analysis/DB254I57/Securitised-Middle-EastCOVID-19-responses-raise-risks (Accessed: I November 2020)

Public Works (2018). Urbanism and law: Master-planning in Lebanon and its impact on people and places [online]:. Available at: https://bit.ly/2E9OLml (Accessed: 17 July 2020)

Rabbat, N. (20I2). 'The Arab revolution takes back the public space', Critical Inquiry, 39(I) [online]. Available at: 10.1086/668055 (Accessed: 5 November 2020) 
Public Spaces as a Venue for Peacebuilding in Lebanon

Reyes, J. (20I5). Direct and indirect forms of violence \& education: The need for a relevant response for out-of-school boys and girls [online]. Available at: https://bit.ly/3eRwNBW (Accessed: 23 July 2020)

Sinno, W. (2020). 'How people reclaimed public spaces in Beirut during the 2019 Lebanese uprising', The Journal of Public Space, 5(I) [online]. Available at: https://doi.org//0.3289|/ips.v5il.1258 (Accessed: 6 July 2020)

UN-Habitat Lebanon (2016). Tripoli City Profile 2016 (Updated September 2017) [online]. Available at: https://data2.unhcr.org/en/documents/download/60482 (Accessed: 18 July 2020)

UN-Habitat (2018) SDG Indicator I I.7.I Training Module: Public Space, United Nations Human Settlement Programme (UN-Habitat), Nairobi [online]. Available at: https://unhabitat.org/sites/default/files/2020/07/indicator_ II.7.I_training module_public sp ace.pdf (Accessed: 23 July 202I)

University of Sheffield (2020). 'Research project to investigate inclusion in public spaces in Lebanon', Department of Landscape Architecture, 7 December [online]. Available at: The https://www.sheffield.ac.uk/landscape/news/research-project-investigate-inclusion-publicspaces-lebanon (Accessed: 23 July 202I) 